\title{
SDC3 Gene
}

National Cancer Institute

\section{Source}

National Cancer Institute. SDC3 Gene. NCI Thesaurus. Code C118950.

This gene is involved in the metabolism of glycosaminoglycans. 